\title{
Leaching of nitrogen, potassium, calcium and magnesium in a sandy soil cultivated with sugarcane ${ }^{(1)}$
}

\author{
Mauro Wagner de Oliveira( ${ }^{(2)}$, Paulo Cesar Ocheuze Trivelin ${ }^{(3)}$, Antônio Enedi Boaretto(3), \\ Taskashi Muraoka ${ }^{(3)}$ and Jeferson Mortatti ${ }^{(3)}$
}

\begin{abstract}
A lysimeter experiment was carried out with sugarcane aiming to evaluate the leaching of nitrogen derived from either urea $\left({ }^{15} \mathrm{~N}\right)$ or the soil/sugarcane crop residues. The leaching of $\mathrm{K}^{+}, \mathrm{Ca}^{2+}$, and $\mathrm{Mg}^{2+}$ was also evaluated. The experiment was a factorial $2 \times 4$. The influencing factors were: firstly, the differential addition of two kinds of sugarcane remains to the soil, simulating conditions of caneplantation renewal after the cane crop harvest, with and without previous straw removal by burning; secondly, four doses of $\mathrm{N}$ : 0,30,60, and $90 \mathrm{~kg} \mathrm{ha}^{-1}$. During the experimental period the total volume of water received by the sugarcane-soil system was $2,015 \mathrm{~mm}$, with $1,255 \mathrm{~mm}$ as precipitation and $760 \mathrm{~mm}$ as irrigation. The loss of $\mathrm{N}$ by leaching from the fertilizer $\left({ }^{15} \mathrm{~N}\right)$ was not detected. In the first three weeks the largest losses of $\mathrm{N}$ by leaching occurred, originating from the soil/sugarcane remains-N. The mean of leached $\mathrm{N}$ during the experimental period of 11 months was of $4.5 \mathrm{~kg} \mathrm{ha}^{-1}$. The mean losses of $\mathrm{K}^{+}, \mathrm{Ca}^{2+}$, and $\mathrm{Mg}^{2+}$ were of 13,320 and $80 \mathrm{~kg} \mathrm{ha}^{-1}$, respectively.
\end{abstract}

Index terms: fertilizers, mineral nutrients, soil transport processes, lysimeters.

\section{Lixiviação de nitrogênio, potássio, cálcio e magnésio em solo arenoso cultivado com cana-de-açúcar}

\begin{abstract}
Resumo - Realizou-se um experimento em lisímetro cultivado com cana-de-açúcar para avaliar a lixiviação

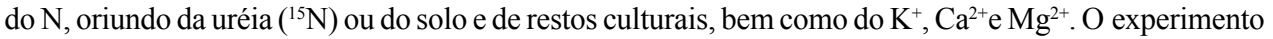
foi um fatorial $2 \times 4$. Os fatores foram: 1) adição diferenciada de dois tipos de restos culturais ao solo, simulando condições de reforma de canavial após a colheita da cana, com ou sem prévia despalha a fogo; 2) quatro doses de $\mathrm{N}: 0,30,60$ e $90 \mathrm{~kg} \mathrm{ha}^{-1}$. Durante o período experimental o volume total de água recebido pela cultura foi de $2.015 \mathrm{~mm}$, sendo $1.255 \mathrm{~mm}$ de precipitações e $760 \mathrm{~mm}$ de irrigações. Não foi verificada perda por lixiviação do $\mathrm{N}$ derivado do fertilizante $\left({ }^{15} \mathrm{~N}\right)$. Nas três primeiras semanas ocorreram as maiores perdas de $\mathrm{N}$ por lixiviação que foram provenientes do solo ou dos restos culturais. $\mathrm{O}$ valor médio do $\mathrm{N}$ lixiviado durante o período experimental de 11 meses foi de $4,5 \mathrm{~kg} \mathrm{ha}^{-1}$. Os valores

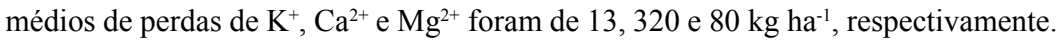

Termos para indexação: adubos, nutrientes minerais, processos de transporte no solo, lisímetro.

(1) Accepted for publication on October 26, 2001.

Extracted from Ph.D. thesis presented by the first author to Universidade de São Paulo (USP), Centro de En ergi a Nuclear na Agricultura (Cena), Piracicaba, SP.

(2) Universidade Federal de Viçosa, Centro de Pesquisa e Melhoramento de Cana-de-Açúcar, Caixa Postal 342, CEP 35430-970 Ponte Nova, MG. E-mail: mwagner@mail.ufv.br

(3) USP-Cena, Caixa Postal 96, CEP 13400-970 Piracicaba, SP. CNPq fellow. E-mail: pcotrive@cena.usp.br, aeboaret@cena.usp.br,muraoka@cena.usp.br, jmatartt@cena.usp.br

\section{Introduction}

The leaching of plant nutrients from agroecosystems is influenced by pedoclimatic and soil-plant system management factors. The following factors have been reported to affect the rate and the total mass of leached ions: soil texture and the cationic and anionic exchange capacity of the soil; the total amount and the rate of rainfall, which influences the soil hydric conditions and the volume of drained soil solution (Salcedo et al., 1988); the dose and the kind of the 
fertilizer (Camargo, 1989); the solubility of the salts and the affinity of their ions for the adsorption sites in the soil; the presence of accompanying ions; the chemical composition of the crop residues incorporated into the soil and microclimatic factors (soil temperature, moisture and aeration), which increase or decrease the mineralization of this new soil organic matter. The intensity with which the nutrients are removed from the soil solution, taken up by the plant roots or immobilized by microorganisms also influences percolation rates and leaching (Ng Kee Kwong \& Deville, 1984; Orlando Filho et al., 1995).

Extraction of the soil solution by means of porous capsules is the method most used in field studies on nutrient leaching (Padovese, 1988; Camargo, 1989; Orlando Filho et al., 1995). However, the collection of percolated solution from laboratory soil columns (Maria et al., 1993; Bittencourt et al., 1996) and from cultivated lysimeters (Ng Kee Kwong \& Deville, 1984; Coelho et al., 1991; Wong et al., 1992; Southwick et al., 1995) have also been used.

Ward et al. (1994) discussed some limitations of soil solution extraction with porous capsules, and Hansen \& Harris (1975) considered that, in many cases, the number of samplings with porous capsules was insufficient. In lysimeters, the natural structure of the soil is modified if the soil material is disturbed during the collection and the reconstruction of the soil profile, which influences the drainage and the solutes percolation. On the other hand, this method avoids problems with sampling, because the volume of percolated solution and the nutrient content allow quantification of leaching losses with greater accuracy (Ng Kee Kwong \& Deville, 1984).

The use of isotope techniques allows the quantification of the movement and the leaching of nutrients derived from the fertilizer, the soil or plant residues. Nitrogenous fertilizers enriched with the isotope ${ }^{15} \mathrm{~N}$ have been frequently used in studies on nitrogen leaching (Takahashi, 1968; Ng Kee Kwong \& Deville, 1984; Padovese, 1988; Salcedo et al., 1988; Camargo, 1989; Coelho et al., 1991).

The present work evaluated, in lysimeters, the leaching of ${ }^{15} \mathrm{~N}, \mathrm{~K}^{+}, \mathrm{Ca}^{2+}$, and $\mathrm{Mg}^{2+}$ in a sandy soil cultivated with sugarcane.

\section{Material and Methods}

The experiment was carried out in lysimeters and the treatments, corresponding to a $2 \times 4$ factorial, were distributed into random blocks, with three replications. The factors were: 1) differential addition of two kinds of sugarcane residues to the soil, simulating conditions of cane-plantation renewal after cane crop harvest, with and without previous straw removal by burning; 2) four doses of $\mathrm{N}: 0,30,60$, and $90 \mathrm{~kg} \mathrm{ha}^{-1}$ of $\mathrm{N}$. In the treatment that simulated cane-plantation renewal, without the removal of straw by burning before harvesting, deceased leaves $\left(4.0 \mathrm{~g} \mathrm{~kg}^{-1}\right.$ of $\left.\mathrm{N}\right)$, tops and stalks $\left(7.8 \mathrm{~g} \mathrm{~kg}^{-1}\right.$ of $\left.\mathrm{N}\right)$ and rhizomes $\left(5.7 \mathrm{~g} \mathrm{~kg}^{-1}\right.$ of $\left.\mathrm{N}\right)$ as sugarcane residues, were incorporated into the soil at a dry matter weight equivalent to $7.0,8.2$ and $10 \mathrm{t} \mathrm{ha}^{-1}$, respectively. Those amounts of sugarcane remains were defined based on the results of Camargo (1989) and Trivelin et al. (1995). In the second treatment, the plant residues were added to the soil in the amounts specified in the first treatment, with the exclusion of the deceased leaves in an attempt to simulate the condition of cane-plantation renewing with straw removal by burning before the previous crop harvesting. All the sugarcane residues were triturated grossly to simulate what occurs with the plant remains during field tillage.

The chemical and physical analyses of the soil used for construction of lysimeters were: $\mathrm{pH}$ in $\mathrm{CaCl}_{2}, 4.4$; $19 \mathrm{~g} \mathrm{~kg}^{-1}$ of O.M.; $10 \mathrm{mg} \mathrm{dm}^{-3}$ of P; $44.1 \mathrm{mg} \mathrm{dm}^{-3}$ of $\mathrm{S}^{-\mathrm{SO}_{4}}{ }^{2-} ; 0.12 \mathrm{mmol}_{\mathrm{c}} \mathrm{dm}^{-3}$ of $\mathrm{K}^{+} ; 1.7 \mathrm{mmol}_{\mathrm{c}} \mathrm{dm}^{-3}$ of $\mathrm{Ca}^{2+}$; $0.3 \mathrm{mmol}_{\mathrm{c}} \mathrm{dm}^{-3}$ of $\mathrm{Mg}^{2+} ; 0.4 \mathrm{mmol}_{\mathrm{c}} \mathrm{dm}^{-3}$ of $\mathrm{Al}^{3+}$; $3.4 \mathrm{mmol}_{\mathrm{c}} \mathrm{dm}^{-3}$ of $\mathrm{H}^{+}+\mathrm{Al}^{3+} ; 38 \%$ of $\mathrm{V} ; 30 \mathrm{~g} \mathrm{~kg}^{-1}$ of very coarse sand; $90 \mathrm{~g} \mathrm{~kg}^{-1}$ of coarse sand; $270 \mathrm{~g} \mathrm{~kg}^{-1}$ of medium sand; $390 \mathrm{~g} \mathrm{~kg}^{-1}$ of fine sandy; $60 \mathrm{~g} \mathrm{~kg}^{-1}$ of very fine sandy; $840 \mathrm{~g} \mathrm{~kg}^{-1}$ of sand total; $60 \mathrm{~g} \mathrm{~kg}^{-1}$ of silt; $100 \mathrm{~g} \mathrm{~kg}^{-1}$ of clay; textural class: sandy.

Before the collection of the soil in the field, the remaining straw from the previous cane crop was removed from the soil surface and the rhizomes of the sugarcane ratoon removed from the underlying soil, in this way avoiding the mixture of the plant residues with the soil.

In the construction of the lysimeters, $220 \mathrm{~L}$ cylindrical plastic drums were used, $60 \mathrm{~cm}$ in diameter and $90 \mathrm{~cm}$ high. Each lysimeter had a drain at the bottom, consisting of a $10 \mathrm{~cm}$ layer of stone fragments $(9 \mathrm{~mm}$ diameter), covered with a Bidim blanket. The solution that percolated through the soil was recovered by means of a PVC tube (5 $\mathrm{mm}$ diameter), below the drain.

The plant residues as well as $\mathrm{CaO}$ and $\mathrm{MgO}$ were added to the superficial layer of the lysimeter soils at a 2:1 relation, respectively, and at sufficient amounts to raise the soil 
basis saturation to $60 \%$. Plant residues, $\mathrm{CaO}$ and $\mathrm{MgO}$ were well mixed with soil.

Ten days after $\mathrm{pH}$ correction and the addition of the plant remains to the soil, three plantlets of sugarcane, variety SP 80 1842, approximately $20 \mathrm{~cm}$ tall, were planted into each lysimeter. Before planting, the fertilizers were applied to a $15 \mathrm{~cm}$ deep hole in the center of the lysimeters. Urea containing 10.10 atom $\%$ of ${ }^{15} \mathrm{~N}$ was applied in doses of $0,30,60$, and $90 \mathrm{~kg} \mathrm{ha}^{-1}$ of nitrogem. Potassium chloride and the triple superphosphate were applied in doses of $120 \mathrm{~kg} \mathrm{ha}^{-1}$ of each of the respective oxides.

During the experimental period, January 8 to December 9, the total volume of water received by the culture was of $2,015 \mathrm{~mm}$, being $1,255 \mathrm{~mm}$ by rainfall and $760 \mathrm{~mm}$ by irrigation.

Whenever the soil solution reached the drain, the collection was performed by determining its mass, while in a subsample the following contents of mineral $\mathrm{N}$ were also quantified: nitrate and ammonium (Keeney \& Nelson, 1982), $\mathrm{K}^{+}, \mathrm{Ca}^{2+}, \mathrm{Mg}^{2+}$ (Zagatto et al., 1981). These values were used to calculate each nutrient mass contained in the drained solution, for each collection. The total mass nutrients drawn through by percolation over the experimental period was the sum of each nutrient mass, for each lysimeter.

In the first collections of the drained soil solution, calorimetric determination of urea with sensitivity of $20 \mathrm{mg} \mathrm{kg}^{-1}$ was performed, using the method of Bremner (1982). When the mass of mineral $\left(\mathrm{N}-\mathrm{NO}_{3}{ }^{-}\right.$and $\mathrm{N}-\mathrm{NH}_{4}{ }^{+}$), determined in a $100 \mathrm{~mL}$ aliquot was greater than $0.3 \mathrm{mg}$, the detection limit of the ATLAS MAT-CH4 mass spectrometer used for isotope analysis of $\mathrm{N}$, the abundance of ${ }^{15} \mathrm{~N}$ was determined in order to evaluate the leaching of the urea $-{ }^{15} \mathrm{~N}$.

The total masses of the leached nutrients for each of the treatments were submitted to variance analysis and the averages compared by the Tukey test at $5 \%$ level of probability.

\section{Results and Discussion}

During the experimental period, 19 collections of the drained solution were carried out, 12 of them in the period from January to March and the others from September to December. For the entire experimental period, the mean value of the drained solution per lysimeter was $357 \pm 22 \mathrm{~mm}$ (mean \pm standard error of the mean).
During the first 90 days of the experiment (from January to March), the accumulated rainfall reached $542 \mathrm{~mm}$, that is, $43 \%$ of the total rainfall registered from January to December 1996. Due to high frequency and low intensity of the rainfall over this period, the solution mass that percolated through soil and reached the drain represented only $37 \%$ of the total mass collected throughout the experimental period. On the other hand, the precipitation occurring from September to the beginning of December, although not very frequent, was intense and reached $615 \mathrm{~mm}$ which represents $49 \%$ of the total rainfall, so causing a non-proportional increase in the mass of the drained solution, that is, $63 \%$ of the total mass.

In the first 48 hours after fertilization, urea was not detected in the leached solution. During this period, the rains totaled $36 \mathrm{~mm}$, resulting in $13 \mathrm{~mm}$, a mean value, for the drained solution in the lysimeters. This drainage volume was due to the high moisture of the soil on the day of fertilization. Wang \& Alva (1996) applied slow release urea, coated urea, onto $1.3 \mathrm{~m}$ columns containing a device to prevent the facilitated displacement of the percolated solution between the wall and the adjacent soil and verified the presence of amide-N (Bremner, 1982) in the percolated solution after five days.

Due to the naturally high ureolytic activity of the soil and plant remains (Oliveira, 1999), it can be assumed that the enzymatic hydrolysis of the urea occurred rapidly with the $\mathrm{NH}_{4}{ }^{+}$produced being retained at the soil sorption sites or suffering nitrification, resulting in the absence of amide- $\mathrm{N}$ in the percolated solution.

During the experimental period, no-measurable losses of $\mathrm{N}$ from urea $\left({ }^{15} \mathrm{~N}\right)$ were observed in those fertilizer-added treatments. It was also observed that the recovery of the ${ }^{15} \mathrm{~N}$ was around $90 \%$ in the soilplant system (Oliveira, 1999), from which approximately $35 \%$ were in soil, therefore evidencing the contribution of the microbiological sorption sites in soil to the absence of the fertilizer- ${ }^{15} \mathrm{~N}$ leaching.

In other studies, in which the fertilizer was labeled with ${ }^{15} \mathrm{~N}$, no (Takahashi, 1968; Padovese, 1988; Salcedo et al., 1988) or insignificant (Coelho et al., 1991) fertilizer-N loss by leaching was observed. However, higher losses by leaching have been documented. Camargo (1989) measured a $28.2 \%$ loss 
when using urea $\left({ }^{15} \mathrm{~N}\right)$ as the $\mathrm{N}$ source; however when the aquammonia was used, the loss of the fertilizer- ${ }^{15} \mathrm{~N}$ was $7.5 \%$.

The greatest leaching of mineral $\mathrm{N}\left(\mathrm{NO}_{3}{ }^{-}, \mathrm{NO}_{2}{ }^{-}\right.$ and $\mathrm{NH}_{4}{ }^{+}$), coming out from the soil and/or from the plant remains, was observed in the first three weeks after planting. In this period, the pluvial precipitation was $137 \mathrm{~mm}$ and the mean value of the drained solution was $45 \mathrm{~mm}$. In this solution, the mean $\mathrm{N}$ concentration was of $5.4 \mathrm{mg} \mathrm{kg}^{-1}$, four times larger than the mean value obtained throughout the experimental period ( $1.3 \mathrm{mg} \mathrm{kg}^{-1}$ of $\left.\mathrm{N}\right)$. That mean value of $1.3 \mathrm{mg} \mathrm{kg}^{-1}$ of $\mathrm{N}$ was lower than that observed by Ng Kee Kwong \& Deville (1984), Salcedo et al. (1988), Camargo (1989) and Orlando Filho et al. (1995), but close to that obtained by Padovese (1988) and Southwick et al. (1995).

The $\mathrm{N}$ in the drained solution was mainly in the form of $\mathrm{NO}_{3}{ }^{-}$, because of the high solubility of the form and lower affinity of its ions for the adsorption sites in the soil, and similar to the results obtained by Ng Kee Kwong \& Deville (1984), Padovese (1988) and Southwick et al. (1995).

No effect was observed on the doses of $\mathrm{N}$ or of the plant remains added to the soil, on the total leached $\mathrm{N}$, by virtue of the microbiological immobilization, as discussed previously (Table 1).

Table 1. The leaching of $\mathrm{N}-\left(\mathrm{NO}_{3}{ }^{-}+\mathrm{NH}_{4}{ }^{+}\right), \mathrm{K}, \mathrm{Ca}$, and $\mathrm{Mg}\left(\mathrm{kg} \mathrm{ha}^{-1}\right)$ from a sandy soil cultivated with sugarcane.

\begin{tabular}{|c|c|c|c|c|c|}
\hline \multirow{2}{*}{$\begin{array}{l}\text { Dose of N } \\
\left(\mathrm{kg} \mathrm{ha}^{-1}\right)\end{array}$} & \multirow[t]{2}{*}{ Treatment } & \multicolumn{4}{|c|}{ Leaching of nutrients $^{(1)}$} \\
\hline & & $\mathrm{N}-\left(\mathrm{NO}_{3}{ }^{-}+\mathrm{NH}_{4}{ }^{+}\right)$ & $\mathrm{K}$ & $\mathrm{Ca}$ & $\mathrm{Mg}$ \\
\hline & & \multicolumn{4}{|c|}{ Not burning } \\
\hline 0 & $\mathrm{~T} 1$ & $3.83 \mathrm{a}$ & $16.9 \mathrm{a}$ & $382 \mathrm{a}$ & $91.4 \mathrm{a}$ \\
\hline 30 & $\mathrm{~T} 2$ & $4.97 \mathrm{a}$ & $10.5 b$ & $282 \mathrm{a}$ & $65.9 \mathrm{a}$ \\
\hline 60 & $\mathrm{~T} 3$ & $4.27 \mathrm{a}$ & $10.3 b$ & $272 \mathrm{a}$ & $74.7 \mathrm{a}$ \\
\hline 90 & $\mathrm{~T} 4$ & $4.60 \mathrm{a}$ & $10.4 \mathrm{~b}$ & $304 a$ & $74.2 \mathrm{a}$ \\
\hline Means & & $4.41 \mathrm{a}$ & $12.0 \mathrm{a}$ & $310 \mathrm{a}$ & $76.6 \mathrm{a}$ \\
\hline & & \multicolumn{4}{|c|}{ Burning } \\
\hline 0 & T5 & $6.08 \mathrm{a}$ & $10.4 \mathrm{~b}$ & $357 \mathrm{a}$ & $91.1 \mathrm{a}$ \\
\hline 30 & T6 & $5.17 \mathrm{a}$ & $10.1 b$ & $278 \mathrm{a}$ & $74.2 \mathrm{a}$ \\
\hline 60 & $\mathrm{~T} 7$ & $4.33 \mathrm{a}$ & $10.9 b$ & $384 a$ & $97.6 \mathrm{a}$ \\
\hline 90 & T8 & $3.23 \mathrm{a}$ & $10.7 \mathrm{~b}$ & $250 \mathrm{a}$ & $70.6 \mathrm{a}$ \\
\hline Means & & $4.70 \mathrm{a}$ & $10.6 \mathrm{a}$ & $317 \mathrm{a}$ & $83.4 \mathrm{a}$ \\
\hline \multicolumn{2}{|l|}{ General means } & 4.56 & 11.3 & 313 & 80 \\
\hline & & \multicolumn{4}{|c|}{ F test } \\
\hline Plant residues (R) & & $0.17^{\mathrm{ns}}$ & $6.20 *$ & $0.55^{\mathrm{ns}}$ & $1.63^{\mathrm{ns}}$ \\
\hline Dose of N (D) & & $1.13^{\mathrm{ns}}$ & $12.8^{*}$ & $2.88^{\mathrm{ns}}$ & $3.68^{\mathrm{ns}}$ \\
\hline $\mathrm{R} \times \mathrm{D}$ & & $1.99^{\mathrm{ns}}$ & $10.3 *$ & $1.45^{\mathrm{ns}}$ & $1.20^{\mathrm{ns}}$ \\
\hline CV (\%) & & 28.71 & 14.80 & 25.30 & 16.50 \\
\hline
\end{tabular}

(1) Means followed by the same letter do not differ significantly at the $5 \%$ level by the Tukey test. ${ }^{\text {ns}}$ No-significant. *Significant at $5 \%$ level by the F test.
Extrapolating the medium value of the total leached $\mathrm{N}$, during the experimental period, a value of $4.5 \mathrm{~kg} \mathrm{ha}^{-1}$ of $\mathrm{N}$ is obtained, with $53 \%$ of this total occurring in the first three weeks, probably due to the limited development of the sugarcane root system, although the fine roots are reported to be very efficient in the absorption of water and nutrients (Ball-Coelho et al., 1992) (Figure 1). Preferential drainage between the internal surface of the lysimeter and the adjacent soil, not yet occupied by the roots of the plants, could also have contributed to that higher leaching rate, agreeing with the observations of Ng Kee Kwong \& Deville (1984).

Nitrogen losses below one meter, verified by Padovese (1988), for fertilizer levels of $100 \mathrm{~kg} \mathrm{ha}^{-1}$ of $\mathrm{N}$, were approximately $0.5 \mathrm{~kg} \mathrm{ha}^{-1}$, being, therefore, smaller than that of the present work. However, losses close to $25 \mathrm{~kg} \mathrm{ha}^{-1}$ of $\mathrm{N}$ were obtained by Salcedo et al. (1988) and Camargo (1989), but losses still higher (70 kg ha-1 of N) were observed by $\mathrm{Ng}$ Kee Kwong \& Deville (1984) in soil with high organic matter content $\left(81 \mathrm{~g} \mathrm{~kg}^{-1}\right)$. In work carried out in the sugarcane-plantation region of the State of São Paulo, Orlando Filho et al. (1995), studying the application of vinasse $\left(150,300\right.$ and $\left.600 \mathrm{~m}^{3} \mathrm{ha}^{-1}\right)$ and mineral fertilizer $\left(60 \mathrm{~kg} \mathrm{ha}^{-1}\right.$ of $\left.\mathrm{N}\right)$ in a Quartz-sandy soil, verified that there was no effect of the application of fertilizer-N or vinasse on $\mathrm{N}$ leaching.

$\mathrm{N}$ leaching obtained by Reichardt et al. (1982) was close to $6 \mathrm{~kg} \mathrm{ha}^{-1}$ of $\mathrm{N}$, when the rainfall oscillated around $1,500 \mathrm{~mm}$ per year and the fertilization rate was in the order of $90 \mathrm{~kg} \mathrm{ha}^{-1}$ of nitrogem. Southwick et al. (1995) demonstrated that, for soils cultivated with sugarcane, the losses of mineral $\mathrm{N}$ by percolation below a depth one meter were also in the order of $6 \%$.

For the total leaching of $\mathrm{K}$, an interactive effect of dose and kind of sugarcane remains was observed only in the treatment with $0 \mathrm{~kg} \mathrm{ha}^{-1}$ of $\mathrm{N}$ and with the addition of plant remains that simulated caneplantation renewing in area without previous straw removal by burning (T1) (Table 1 ).

The largest amount of $\mathrm{K}$ incorporated into the soil, due to presence of deceased leaves (530 $\mathrm{mg}$ of $\mathrm{K}$, more than in the other kind of plant remains), was associated with the fast liberation of $\mathrm{K}$ from the straw (Oliveira et al., 1999) and with limited root and aerial part development in the T1 (Oliveira, 1999), 
which was probably responsible for the increased leaching observed in these treatments (1.8 times more than the average of the other treatments).

The mean value of total for $\mathrm{K}$ in $\mathrm{T} 1 \mathrm{was}$ of $485 \mathrm{mg}$, while the average of the other treatments was $266 \mathrm{mg}$, with the standard error being 15 and $11 \mathrm{mg}$ of $\mathrm{K}$ for each lysimeter, respectively. Extrapolating these values to $1 \mathrm{ha}$, the mean leaching values were approximately 17 and $9 \mathrm{~kg}$ of $\mathrm{K}$, representing a mean loss of 8 and $4 \%$, respectively, for the $\mathrm{K}$ added as fertilizer and cultural remains, plus the exchangeable $\mathrm{K}$ from the soil in the lysimeters, calculated using the initial values of the chemical analysis of the soil used for construction of lysimeters (Figure 2). Wong et al. (1992) studied lysimeters cultivated with maize and later rice, also, observing that the $\mathrm{K}$ losses were less

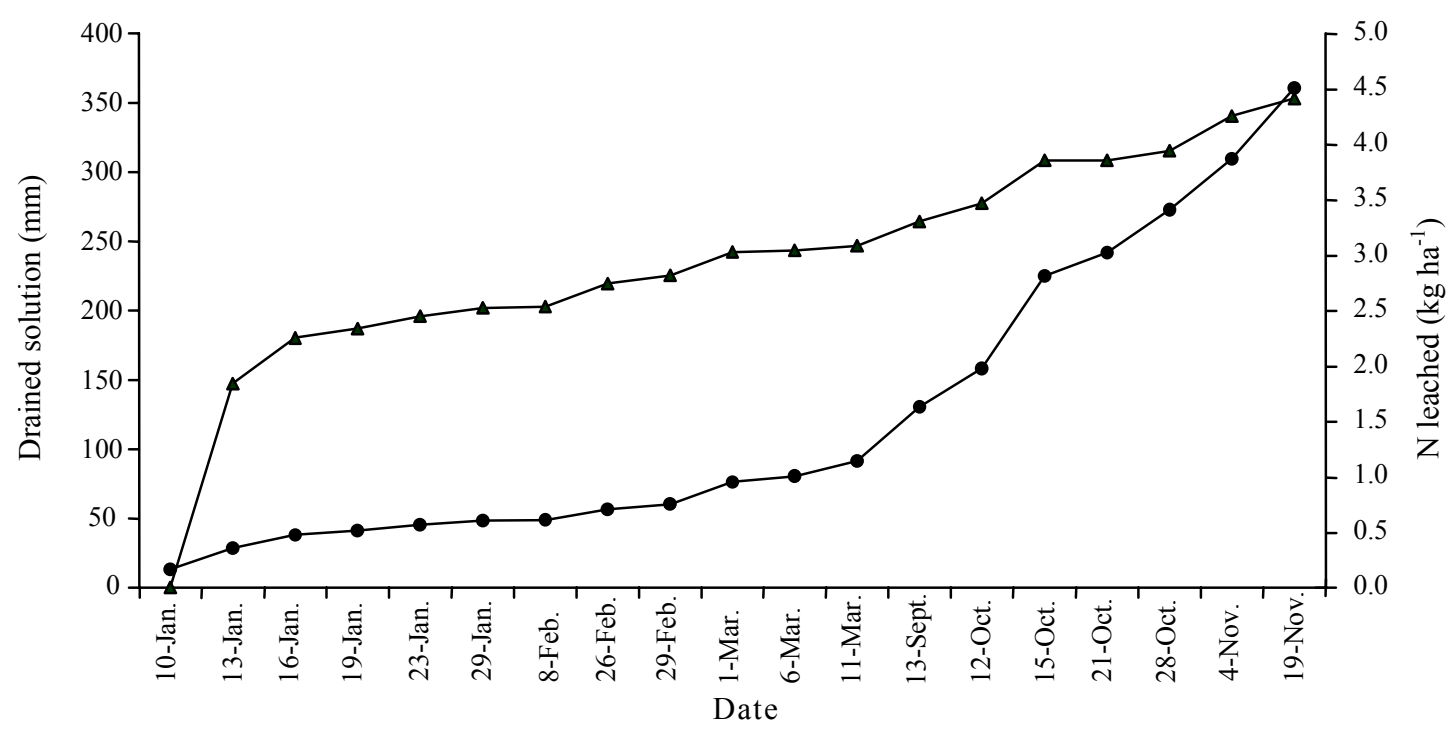

Figure 1. Drained solution $(\boldsymbol{O})$ and amounts of $\mathrm{N}\left(\mathrm{NO}_{3}{ }^{-}+\mathrm{NH}_{4}{ }^{+}\right)(\boldsymbol{\Delta})$ leachead from sandy soil cultivated with sugarcane.

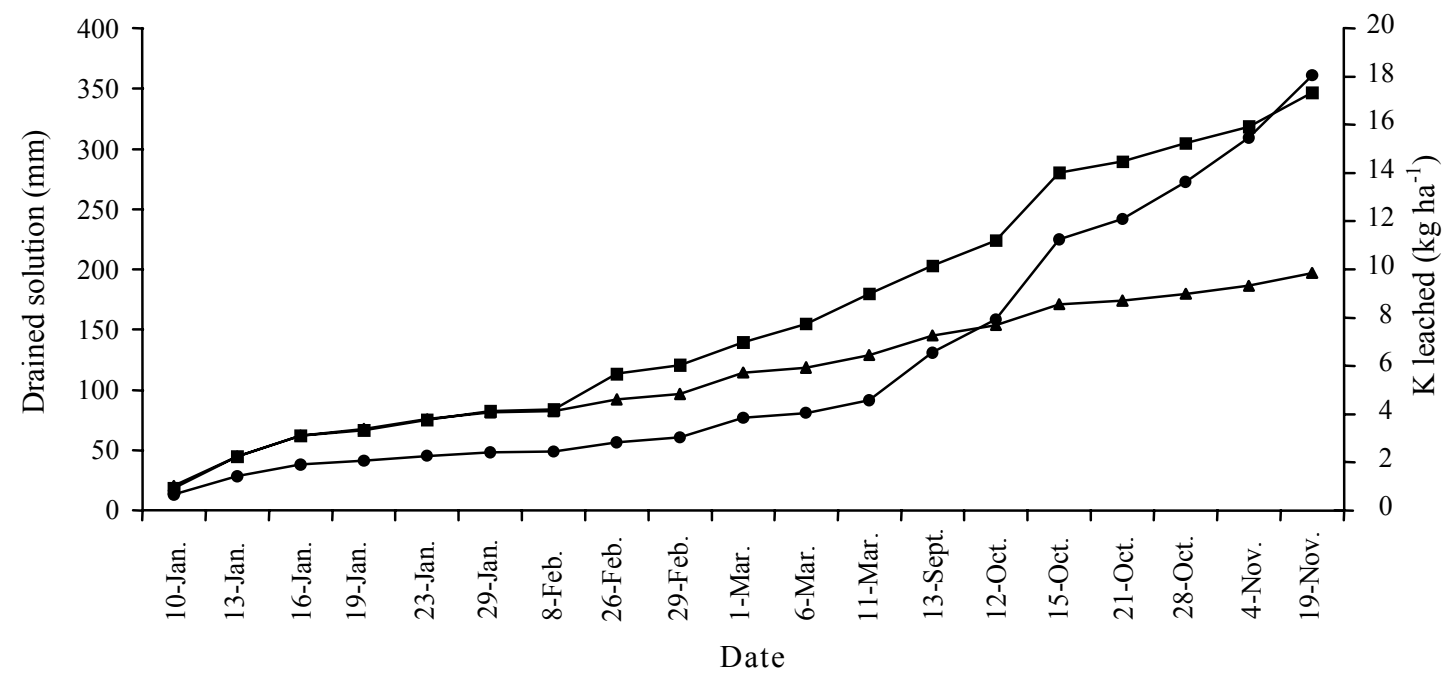

Figure 2. Drained solution $(\boldsymbol{O})$ and amounts of K leached in the treatment $1(\boldsymbol{\square})$ and other treatment $(\boldsymbol{\Delta})$ from sandy soil cultivated with sugarcane. 
than $10 \%$ of the exchangeable $\mathrm{K}$ of the soil and added fertilizer.

In sugarcane crop fertilized with $100 \mathrm{~kg} \mathrm{ha}^{-1}$ of $\mathrm{K}_{2} \mathrm{O}$ and cultivated in Red-Yellow dystrophic Podsol in Northeast Brazil, Salcedo \& Sampaio (1991) verified that the $\mathrm{K}$ loss for percolation below $100 \mathrm{~cm}$ was $9 \mathrm{~kg} \mathrm{ha}^{-1}$. For high doses of $\mathrm{K}\left(388 \mathrm{~kg} \mathrm{ha}^{-1}\right.$ as $\left.\mathrm{K}_{2} \mathrm{O}\right)$ applied as vinasse $\left(200 \mathrm{~m}^{3} \mathrm{ha}^{-1}\right)$, Padovese (1988) did not observe percolation of this element at a depth of $100 \mathrm{~cm}$. However, $\mathrm{K}$ losses, by leaching, varying of 64 to $136 \mathrm{~kg} \mathrm{ha}^{-1}$ were verified by $\mathrm{Ng}$ Kee Kwong \& Deville (1984) in lysimeters cultivated with sugarcane, which were fertilized annually with high doses of $\mathrm{KCl}$, equivalent to $285 \mathrm{~kg} \mathrm{ha}^{-1}$ year $^{-1}$ of $\mathrm{K}_{2} \mathrm{O}$.

No treatment effect was observed for $\mathrm{Mg}$ and $\mathrm{Ca}$ leaching (Table 1). The mean mass values for $\mathrm{Mg}$ and $\mathrm{Ca}$ extrapolated for 1 ha were of 80 and $320 \mathrm{~kg} \mathrm{ha}^{-1}$, respectively (Figure 3 ). Wong et al. (1992), in studies using $1.35 \mathrm{~m}$ deep lysimeters cultivated with corn, reported high $\mathrm{Ca}$ losses (312 $\mathrm{kg} \mathrm{ha}^{-1}$ ) when finely milled, calcium hydroxide was applied at a dose of $1,025 \mathrm{~kg} \mathrm{ha}^{-1}$, to correct soil acidity.

The losses by percolation were related to the volume of the drained solution, more notably for $\mathrm{Ca}$ (Figure 3). On average, it was shown that the total loss of $\mathrm{Ca}$ and $\mathrm{Mg}$, by percolation, at the end of the experimental period, corresponded to 64 and 39\% of $\mathrm{Ca}$ and $\mathrm{Mg}$ applied as corrective of soil acidity. In this corrective, a mixture of $\mathrm{CaO}$ and $\mathrm{MgO}$, the relationship Ca: $\mathrm{Mg}(\mathrm{w} / \mathrm{w})$ was 2.38:1.00, although in the leached solution this relationship rose to 3.95:1.00, demonstrating higher percolation of $\mathrm{Ca}$ than of magnesium. Results of chemical analysis of soil samples collected before the addition of the corrective and at the end of the experimental period (Oliveira,1999) showed a decrease in the relationship between exchangeable $\mathrm{Ca}: \mathrm{Mg}$, demonstrating greater leaching of $\mathrm{Ca}$ in relation to magnesium.

The greater solubility of $\mathrm{Ca}(\mathrm{OH})_{2}$ and $\mathrm{Mg}(\mathrm{OH})_{2}$ resulting from hydrolysis of $\mathrm{CaO}$ and $\mathrm{MgO}$ probably is one of the causes for high $\mathrm{Ca}$ leaching. However, only the solubility factor does not entirely explain the differential losses between $\mathrm{Ca}$ and $\mathrm{Mg}$, since the hydroxides resulting from hydrolysis of $\mathrm{CaO}$ and $\mathrm{MgO}$, that is, $\mathrm{Ca}(\mathrm{OH})_{2}$ and $\mathrm{Mg}(\mathrm{OH})_{2}$, have been reported to have a relative solubility higher than 200:1 (Lide, 1998).

Another aspect to be considered is, when soil correction is carried out with $\mathrm{CaCO}_{3}$ and/or $\mathrm{MgCO}_{3}$, the losses of $\mathrm{Ca}$ and $\mathrm{Mg}$ are not significant (Maria et al., 1993; Bittencourt et al., 1996). Therefore, the high $\mathrm{Ca}$ and $\mathrm{Mg}$ leaching observed in the present study should not occur in commercial sugarcane plantations where $\mathrm{CaCO}_{3}$ is normally used for the

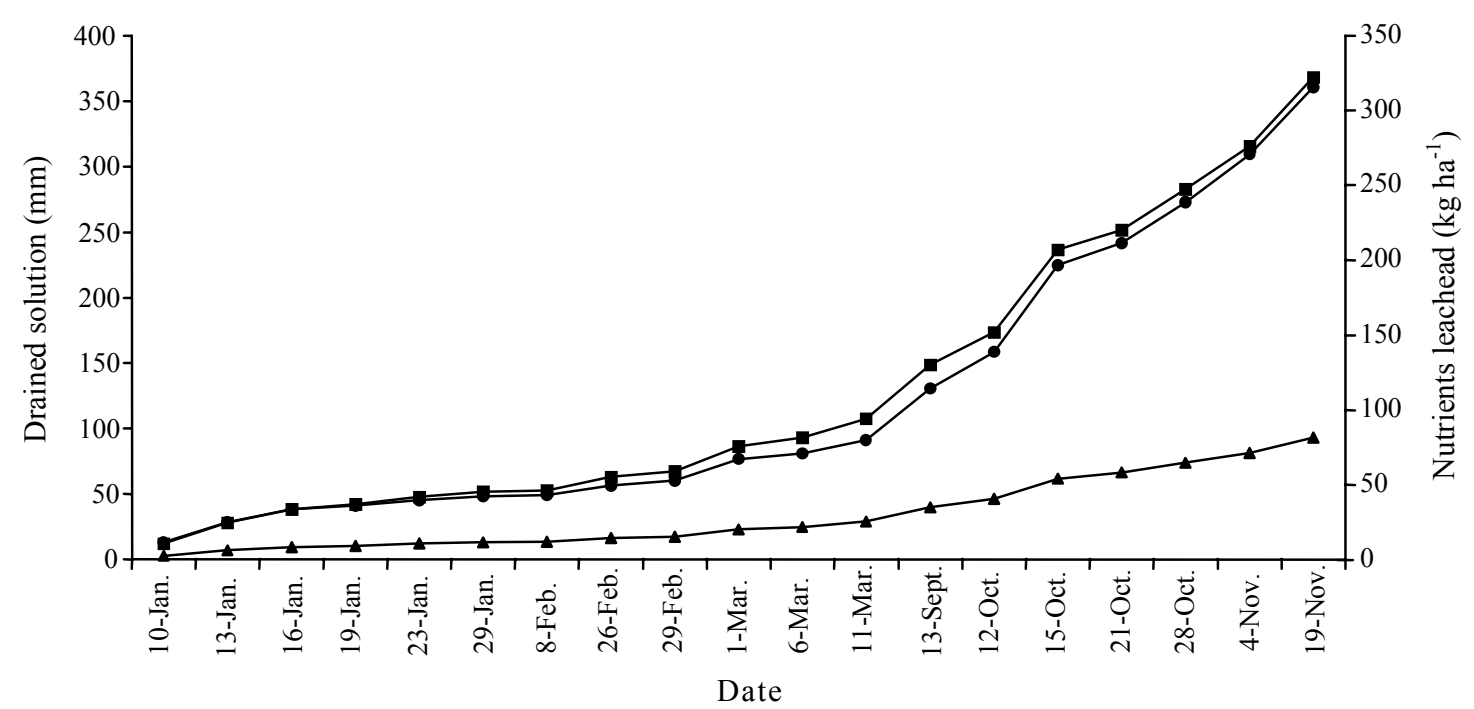

Figure 3. Drained solution ( and amount of $\mathrm{Ca}$ and $\mathrm{Mg}$

(A) leached from sandy soil cultivated with sugarcane. 
correction of soil acidity. Besides being much less soluble than $\mathrm{Ca}$ and $\mathrm{Mg}$ hydroxide, these salts do not possess the fineness of the p.a. grade chemical reagents.

\section{Conclusions}

1. There are no losses of $\mathrm{N}$ derived from fertilizer.

2. The loss of $\mathrm{NO}_{3}{ }^{-}$and $\mathrm{NH}_{4}{ }^{+}$are of the magnitude of $5 \mathrm{~kg} \mathrm{ha}^{-1}$.

3. The mean losses for $\mathrm{K}^{+}, \mathrm{Ca}^{2+}$, and $\mathrm{Mg}^{2+}$ are of 13,320 , and $80 \mathrm{~kg} \mathrm{ha}^{-1}$, respectively.

\section{Acknowledgements}

To the Usina Costa Pinto S.A. Açúcar e Álcool for the logistic support; to Fapesp, CNPq and Capes for financial support.

\section{References}

BALL-COELHO, B.; SAMPAIO, E. V. S. B.; TIESSEN, H.; STEWART, J. W. B. Root dynamics in plant and ratoon crops of sugar cane. Plant and Soil, Dordrecht, v. 142, p. 297-305, 1992.

BITTENCOURT, V. C.; PAIXÃO, A .C. S.; ALMEIDA, M. J.; BEAUCLAIR, E. G. F.; ALVES, M. C. Dinâmica do cálcio e do magnésio em um solo cultivado com canade-açúcar. STAB Açúcar, Álcool e Subprodutos, Piracicaba, v. 14, n. 3, p. 6-19, 1996.

BREMNER, J. M. Nitrogen-urea. In: PAGE, A. L.; MILLER, R. H.; KEENEY, D. R. (Ed.). Methods of soil analysis. 2. ed. Madison: American Society of Agronomy, 1982. p. 699-709. (Agronomy, 9).

CAMARGO, P. B. Dinâmica do nitrogênio dos fertilizantes: uréia $\left({ }^{15} \mathrm{~N}\right)$ e aquamônia $\left({ }^{15} \mathrm{~N}\right)$ incorporados ao solo na cultura de cana-de-açúcar. $1989.104 \mathrm{f}$. Dissertação (Mestrado) - Centro de Energia Nuclear na Agricultura, Universidade de São Paulo, Piracicaba.

COELHO, A. M.; FRANÇA, G. E.; BAHIA, A. F. C.; GUEDES, G. A. A. Balanço de nitrogênio $\left({ }^{15} \mathrm{~N}\right)$ em um Latossolo Vermelho-Escuro, sob vegetação de cerrado, cultivado com milho. Revista Brasileira de Ciência do Solo, Campinas, v. 15, p. 187-193, 1991.

HANSEN, E. A.; HARRIS, A. R. Validity of soil-water samples collected with porous ceramic cups. Soil Science Society of America Proceedings, Madison, v. 39, p. 528536, 1975.
KEENEY, D. R.; NELSON, D. W. Nitrogen-inorganic forms. In: PAGE, A. L.; MILLER, R. H.; KEENEY, D. R. (Ed.). Methods of soil analysis. 2. ed. Madison: American Society of Agronomy, 1982. p. 643-689. (Agronomy, 9).

LIDE, R. D. CRC handbook of chemistry and physics. 78. ed. Boca Raton: CRC, 1998. 857 p.

MARIA, L. C.; ROSSETTO, R.; AMBROSANO, E. J.; CASTRO, O. M. Efeito da adição de diferentes fontes de cálcio no movimento da cátions em colunas de solo. Scientia Agricola, Piracicaba, v. 50, n. 1, p. 87-98, 1993.

NG KEE KWONG, K. F.; DEVILLE, J. Nitrogen leaching from soils cropped with sugarcane under the humid tropical climate of Mauritius, Indian Ocean. Journal of Environmental Quality, Madison, v. 13, n. 3, p. 471474, 1984.

OLIVEIRA, M. W. Dinâmica do nitrogênio da uréia $\left({ }^{15} \mathrm{~N}\right)$ no sistema solo-cana-de-açúcar com ou sem queima da palhada. 1999. $93 \mathrm{f}$. Tese (Doutorado) - Centro de Energia Nuclear na Agricultura, Universidade de São Paulo, Piracicaba.

OLIVEIRA, M. W.; TRIVELIN, P. C. O.; PENATTI, C. P.; PICCOLO, M. C. Decomposição e liberação de nutrientes da palhada de cana-de-açúcar em campo. Pesquisa Agropecuária Brasileira, Brasília, v. 34, n. 12, p. 2359-2362, dez. 1999.

ORLANDO FILHO, J.; BITTENCOURT, V. C.; ALVES, M. C. Aplicação de vinhaça em solo arenoso do Brasil e poluição do lençol freático com nitrogênio. STAB Açúcar, Álcool e Subprodutos, Piracicaba, v. 13, n. 6, p. 14-16, 1995.

PADOVESE, P. P. Movimento e perdas de nitrogênio e potássio num solo com cana-de-açúcar (Saccharum spp.). 1988. 118 f. Dissertação (Mestrado) - Escola Superior de Agricultura Luiz de Queiroz, Piracicaba.

REICHARDT, K.; LIBARDI, P. L.; URQUIAGA, S. C. Fate of fertilizer nitrogen in soil-plant systems with emphasis on the tropics. In: INTERNATIONAL SYMPOSIUM ON AGROCHEMICAL: fate in food and the environmental using isotope techniques, 1982, Rome. Proceedings... Vienna: International Atomic Energy Agency, 1982. p. 177-190.

SALCEDO, I. H.; SAMPAIO, E. V. S. B. Dinâmica de nutrientes em cana-de-açúcar. V. Balanço de K em quatro ciclos de cultivo. Pesquisa Agropecuária Brasileira, Brasília, v. 26, n. 9, p. 1323-1335, set. 1991. 
SALCEDO, I. H.; SAMPAIO, E. V. S. B.; CARNEIRO, C. J. G. Dinâmica de nutrientes em cana-de-açúcar. IV. Perdas de $\mathrm{N}$ por lixiviação em cana-planta fertilizada com uréia $-{ }^{15}$ N. Pesquisa Agropecuária Brasileira, Brasília, v. 23, n. 7, p. 725-732, jul. 1988.

SOUTHWICK, L. M.; WILLIS, G. H.; JOHNSON, D. C.; SELIM, H. M. Leaching of nitrate, atrazine, and metribuzin from sugarcane in Southern Louisiana. Journal of Environmental Quality, Madison, v. 24, p. 684-690, 1995.

TAKAHASHI, D. T. Fate of ammonium and nitrate fertilizer in lysimeter studies with ${ }^{15} \mathrm{~N}$. Hawaiian Planters' Record, Aiea, v. 58, n. 1, p. 1-11, 1968.

TRIVELIN, P. C. O.; VICTORIA, R. L.; RODRIQUES, J. C. S. Aproveitamento por soqueira de cana-de-açúcar de final de safra do nitrogênio da aquamônia- ${ }^{15} \mathrm{~N}$ e uréia- ${ }^{15} \mathrm{~N}$ aplicado ao solo em complemento à vinhaça. Pesquisa Agropecuária Brasileira, Brasília, v. 30, n. 12, p. 1375-1385, dez. 1995.
WANG, F. L.; ALVA, A. K. Leaching of nitrogen from slowrelease urea sources in sandy soils. Soil Science Society of America Journal, v. 60, p. 1454-1458, 1996.

WARD, A. L.; KACHANOSKI, R. G.; ELRICH, D. E. Laboratory measurements of solute transport using time domain reflectometry. Soil Science Society of America Journal, Madison, v. 58, p. 1031-1039, 1994.

WONG, M. T. F.; KRUIJS, A. C. B. M.; JUO, A. S. R. Leaching loss of calcium, magnesium, potassium and nitrate derived from soil, lime and fertilizers as influenced by urea applied to undisturbed lysimeters in southeast Nigeria. Fertilizer Research, Dordrecht, v. 31, p. 281-289, 1992.

ZAGATTO, E. A. G.; JACINTHO, A. O.; REIS, B. F.; KRUG, F. J.; BERGAMIN FILHO, H.; PESSENDA, L. C. R.; MORTATTI, J.; GINÉ, M. F. Manual de análises de plantas e águas empregando sistemas de injeção em fluxo. Piracicaba: USP, 1981.45 p. Publicação especial. 